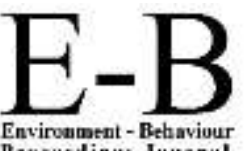
Enviroument - Bethaviour

\section{AcE-Bs2021KotaBharu}

https://www.amerabra.org; https://fspu.uitm.edu.my/cebs; https://www.emasemasresources.com/ $9^{\text {th }}$ Asian Conference on Environment-Behaviour Studies Perdana Kota Bharu, Kelantan, Malaysia, 28-29 Jul 2021

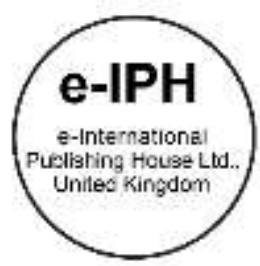

\title{
Company Performance during Covid-19: Impact of leverage, liquidity and cash flows
}

\author{
Sara NaquiaHanim Shaharuddin ${ }^{1}$, Radziah Mahmud², \\ Nor Khadijah Mohd Azhari ${ }^{3}$, Widya Perwitasari ${ }^{4}$ \\ ${ }^{1}$ Tymba Education, Professional Accountancy Center \\ 28a, 1, Jalan Tiara,USJ 9, Subang Jaya, Selangor, Malaysia \\ 2Faculty of Accountancy, Universiti Teknologi MARA Selangor \\ Puncak Alam Campus, Selangor, Malaysia \\ 3Department of Business Management, Universiti Teknologi MARA Penang \\ Permatang Pauh Campus, Penang, Malaysia \\ ${ }^{4}$ Faculty of Economics and Business, Universitas Indonesia, Indonesia \\ sara14381@gmail.com, radzi132@uitm.edu.my, dijah4041@gmail.com,widyap@ui.ac.id \\ Tel: 012-691269
}

\begin{abstract}
Due to the movement control order, company performance is predicted to be highly affected by Covid-19 pandemic. Thus, this study seeks to examine the impact of leverage, liquidity and cash flows from operations towards company performance during the Covid-19 pandemic. Using secondary data from public listed companies on Bursa Malaysia with two financial quarters in the financial year 2020, it is found that there is a significant impact of liquidity and cash flows from operations on company performance. This study may contribute as additional literature to future studies and provide sights to regulators in dealing with the pandemic outbreak.
\end{abstract}

Keywords: Covid-19; leverage; liquidity; cash flows

eISSN: 2398-4287@ 2021. The Authors. Published for AMER ABRA cE-Bsby e-International Publishing House, Ltd., UK. This is an open access article under the CC BYNC ND license (http://creativecommons.org/licenses/by-nc-nd/4.0/). Peer-review under responsibility of AMER (Association of Malaysian Environment-Behaviour Researchers), ABRA (Association of Behavioural Researchers on Asians/Africans/Arabians) and CE-Bs (Centre for Environment-Behaviour Studies), Faculty of Architecture, Planning \& Surveying, Universiti Teknologi MARA, Malaysia.

DOI: https://doi.org/10.21834/ebpj.v6i17.2878

\subsection{Introduction}

The outbreak of the Covid-19 pandemic at the end of 2019 has become a severe worldwide problem as the virus already infected more than 175 million people and taken the lives of about 3.8 million people*. Companies need to be prepared and apply every crisis response plan to face more stringent financing requirements and higher interest costs, either as temporary or long-term resolution (International Monetary Fund, 2020). The economic downturn caused by the Covid-19 pandemic outbreak is by far the worst since the global recession in 1930 (Shen et al., 2020). As the pandemic continues to spread, Malaysia is not spared from being hit by the pandemic's adverse impacts

\footnotetext{
*WorldOMeter. (2021). Coronavirus. https://www.worldometers.info/coronavirus/ accessed date on 15 March 2021
}

eISSN: 2398-4287@ 2021. The Authors. Published for AMER ABRA cE-Bs by e-International Publishing House, Ltd., UK. This is an open access article under the CC BYNCND license (http://creativecommons.org/licenses/by-nc-nd/4.0/). Peer-review under responsibility of AMER (Association of Malaysian Environment-Behaviour Researchers), ABRA (Association of Behavioural Researchers on Asians/Africans/Arabians) and CE-Bs (Centre for Environment-Behaviour Studies), Faculty of Architecture, Planning \& Surveying, UniversitiTeknologi MARA, Malaysia.

DOI: https://doi.org/10.21834/ebpj.v6i17.2878 
on society's health and the nation's economic condition such as the hospitality industries like tourism and hotel industry including transportation industry like aviation as researched by Foo et al., (2020) and others.

The Movement Control Order (MCO) implementation has impacted the world's economies by changing how companies operated. The Malaysian government also followed suit in implementing the MCO by quickly closing the borders and urged the citizens to stay home. Businesses, schools and universities were forced to shut down, and employers instructed employees to work from home. At the same time, students and teachers carried on their learning process via various online platforms such as Google Meet, Microsoft team and Zoom. Additionally, sanctions and fines were issued out to those who failed to abide by the MCO standard of procedures. The MCO triggered a barrier for companies to sustain profitability as only essential businesses like health care and food supply companies could operate but with strict Covid-19 standard of procedures in place. Due to the inability to generate fund internally, this action resulted in companies turning to additional debts to finance the business activities to stay afloat (International Monetary Fund, 2020).

The MCO has hindered companies from operating at total capacity to contain the Covid- 19 virus from spreading. It has been predicted that companies will experience higher leverage as more debt is taken in order to sustain business due to the sudden reduction of the Covid-19-induced demand for goods and services. This will further deteriorate current and expected revenues and income that eventually decays the market value of a company's assets.

The MCO limits people from travelling and even working, resulting in lower purchasing power. People have less income to spend, and fewer households are allowed to leave the house. This will result in the reduction of demand in the market. When the demand for goods and services have been reduced drastically, sales will diminish (Shen et al., 2020). The repercussion from the reduction in sales leads to a reduction in liquidity and cash flows from companies' operations as both items are the crucial elements for a company to carry out its business activities. If both elements of liquidity and cash flows are not efficiently managed, especially in a time of crisis like the Covid-19 pandemic, the company may not sustain itself in the market (Frank \& James, 2014). This will eventually impact the company performance negatively for the financial year 2020.

Studies on Covid-19 impact on company performance have been carried out in Indonesia and China (Purwanto et al., 2020; Shen et al., 2020). While in Malaysia, the studies on the area are still minimal. The studies covered the measures taken by the Malaysian government to curb the spread of the virus and analysis on the impact of Covid-19 on the stock market, small-medium business and several industries (Che Omar et al., 2020; Foo et al., 2020; Hasanat et al., 2020) . None of these studies covered the performance of companies affected by the Covid-19 pandemic outbreak. Therefore, this study is significant in reducing the literature gap by providing insights into the current impact of the Covid-19 pandemic outbreak on companies' performance by examining the impact of the leverage, liquidity, and cash flows from the operation on company performance from January 2020 to September 2020.

\subsection{Literature Review}

In order to curb the impact of the Covid-19 pandemic, many businesses are forced to shut down except for essential businesses and people initially are required to stay at home, keeping personal hygiene and practice social distancing intact (Tang, 2020). Thus, in general, businesses face challenges such as weak economic and financial results, demand cutbacks, supply chain disruptions, knock-on effects of troubled sectors on employment, uncertain future business direction, potential inadequacy of liquidity and working capital, and higher bankruptcy risk (Che Omar et al., 2020). Hence, the adverse effect of the Covid-19 pandemic may impact the leverage, liquidity and cash flows from the operation of the companies that consequently affect the financial performance of the companies.

\subsection{Leverage and company performance}

Leverage ratio is used to measure the company's debt financing and it indicates the ability of the company to pay its long-term debts. Since companies may have difficulty in sustaining their business during the Covid-19 pandemic period, companies may turn to additional debts as alternative sources in financing their activities (International Monetary Fund, 2020). While a reasonable level of debt financing can benefit the economy to encourage public consumption and investment, excessive debts will expose the companies to higher business risks as the companies may not be able to meet their financial obligations when the payments are due. Previous literature suggests a negative relationship between the company financial leverage and company performance (Hedija \& Němec, 2021). Over-reliance on debt financing may increase the business' riskiness that leads to financial problems which eventually deteriorate the companies' activities and performance. However, it found that the relationship between leverage and company performance to be positive in other studies such as Chabachib et al., (2020). It argued that higher debt financing would restrain managerial discretion, encourage management to strategise their activities to obtain higher profits, gain creditors confidence, and boost the growth of business activities (Chabachib et al., 2020; Hedija \& Němec, 2021). Therefore, the relationship between leverage and company performance is indecisive and worth to be investigated.

\subsection{Liquidity and company performance}

Measures imposed by the government to curb the spread of Covid-19 have created difficulties for the companies in managing their working capital due to a drop in demand, delay in receivables collection, and necessity to settle obligations to significant suppliers (EY, 2020). These difficulties may affect the liquidity position of the company as liquidity ratio measures the ability of the company to manage its shortterm obligations. (Zimon \& Dankiewicz, 2020) found that companies have a higher tendency to maintain good liquidity before the outbreak of the Covid-19 pandemic than during the Covid-19 pandemic outbreak. Companies that have managed their liquidity efficiently are expected to gain more profit (Hong et al., 2021) because they can make better investment decisions while meeting their short-term financial obligation without default. However, the empirical evidence on the influence of liquidity on performance is inconclusive. A study was done by Li, Musah, Kong, Adjei Mensah, et al., (2020) indicates a negative relationship between liquidity and performance. It argued that having 
higher liquidity implies an inefficient utilisation of asset in generating profits. Companies recommended maintaining a good and balance liquidity position to sustain their business and make sound investment decisions (Li et al., 2020).

\subsection{Cash flows and company performance}

Cash flows have always been an important element of a company's survival and investment decision making will be based on whether the company has enough cash to invest or not, which will impact the company's performance. During the Covid-19 pandemic outbreak, Shafi et al., (2020) conclude that companies may face the risk of bankruptcy and going concern if they do not retain high cash flows during the pandemic outbreak. Thus, companies need to strengthen their cash flows position to ease the long-term adverse impact of the Covid-19 pandemic outbreak and MCO (Shafi et al., 2020). It is the utmost priority in business management to ensure cash flows from operations are always positive in order to ensure strength and steadiness of business operations for a foreseeable period of time (Wijewardana \& Munasinghe, 2018).

Literature suggests that operating cash flows have a significant positive relationship with company performance (Alshammari, 2020). Companies that have net cash inflows from the operation may experience less liquidity crisis as they can generate cash from the primary business activities (Alslehat \& Al-Nimer, 2017). Nonetheless, Zhang et al., (2015) suggest that a lower cash flow level may lead to better company performance, as having high cash may indicate inefficient cash management governance (Alshammari, 2020). Hence, the impact of cash flows on the company's performance is inconsistent and more empirical evidence is required to establish the relationship.

\subsection{Company size as a control variable and company performance}

The model used in this study includes company size since it is regarded as one of the determinants of company performance. Nevertheless, the empirical evidence in relation to the impact of company size on company performance is inconsistent. A few studies such as Hedija \& Němec, (2021) and Li, Musah, Kong, Adjei Mensah, et al., (2020) support the view that company size has a favourable influence on performance. Large companies may have better performance through business diversity, economies of scale, lower costs, and higher competitive power. On the other hand, it is argued that larger companies could not respond to the dynamic market evolution due to formalisation procedures involved in larger companies compared to smaller companies. Consequently, the financial performance of smaller companies may be superior (Majumdar, 1997). Therefore, the size of companies may have a positive or negative influence on company performance.

\subsection{Measurement of the variables}

Table 1 shows the summary of the variables' measurement used in this study.

\begin{tabular}{lll} 
& \multicolumn{2}{c}{ Table 1: Measurements of Variables } \\
\hline Variables & Measurements & Prior Studies \\
\hline Return on Assets (ROA) & Profit after tax / Total Assets & Wijewardana \& Munasinghe (2018); Shen et al., \\
& & $(2020)$ \\
Return on Equity (ROE) & Profit after tax / Total Equity & Wijewardana \& Munasinghe (2018); Shen et al., \\
& & $(2020)$ \\
Leverage (LEV) & Debt to Equity ratio & Liang et al. (2020); Wijewardana \& Munasinghe \\
Liquidity (LIQ) & Current Assets less Inventory / Current Liabilities & (2018) \\
Cash Flows (CFO) & Cash Flows from Operating Activities / Total Assets & Wijewardana \& Munasinghe (2018) \\
Size & Natural log of Total Assets & Abdullah \& Tursoy (2021) \\
& & \\
\hline
\end{tabular}

\subsection{Trade-off Theory}

Following Abdullah and Tursoy (2021) this study applies the trade-off theory. This theory explains the usage of debt and equity-based on corporate taxes, which Myers initiated in 1977. It supports the advantages of debt financing. The companies balance the trade-off between the debt benefits and debt costs because leverage may positively impact performance (Hassan and Samour, 2015). To ensure the company's sustainability, the company should manage its liquidity efficiently to meet its financial obligations while maximising its shareholders' wealth and consequently the companies' performance. Thus, companies must balance the trade-off between the costs and benefits of handling their liquidity (Orshi, 2016). According to the transaction cost motive, having high cash enables companies to reduce transaction costs to raise funds (Tahir et al., 2016). Nevertheless, precautionary motive views that companies can finance their business activities using cash holding if other financing sources are unavailable and unaccessible. Thus, the trade-off between the marginal cost and benefit of holding cash is essential.

\subsection{Research Methodology}

In conducting this study, secondary data was used to collect the necessary information. The data have been collected through Refinitiv Eikon published by Thomson Reuters. After eliminating the outliers and missing data, this study was carried out based on 517 public listed companies in Malaysia using two-quarters of the financial data in the year 2020. 
This study presents quantitative analysis as well as theoretical data analysis. To analyze the data, both descriptive and correlations are used to examine the relationship between the considered variables. Furthermore, this study employs Multivariate Ordinary Least Square (OLS) regression to determine if there is a relationship between financial performance, ROA and ROE which are the dependent variables and independent variables namely leverage, liquidity, and cash flow from operations.

The data in this study were analysed using Python Pandas programming software. It was believed that this kind of analysis method still lacked in usage among researchers, especially in the accounting and finance area. According to Lee (2014), Python is an interpretive, interactive, and object-oriented computer language with a large number of network-oriented function libraries, which can improve data acquisition efficiency. Pandas offer data structures and operations for manipulating numerical tables and time series by creating the coding system based on the data and information required for this study.

\subsection{Findings and Discussion}

\subsection{Descriptive Statistics}

Result in Table 2 shows that, on average, ROA and ROE are -0.00267 per cent and -0.004 per cent, respectively. Concerning independent variables, the mean of leverage (LEV), liquidity (LIQ) and cash flows from operation (CFO) are $0.328,1.428$ and 0.021 , respectively. Generally, negative RM0.00267 profits generated from every RM1 of assets held by companies and negative RM0.004 profits generated from every RM1 of equity held. In terms of leverage, RM0.328 debts will cover RM1 equity, and on the other hand, for liquidity, it seems that the companies generally have sufficient liquid assets to cover their current liabilities. In March 2020, due to the implementation of MCO by the government, numerous companies cannot operate their business as usual. Based on Table 2, this study provides evidence that the cash flows generated from operations might be worse and descent due to the implementation of the MCO as indicated by low level of cash flows from operation to total assets ratio. Generally, companies use this ratio to estimate cash availability in future periods based on projected operations.

Table 2: Descriptive Statistics

\begin{tabular}{lcccccc}
\hline & ROA & ROE & LEV & LIQ & Cash Flow & Size \\
\hline Mean & -0.00267 & -0.004 & 0.328 & 1.428 & 0.021 & 19.946 \\
Standard Deviation & -0.0302 & 0.058 & 0.254 & 0.829 & 0.067 & 1.422 \\
Minimum & -0.197 & -0.592 & 0.001 & 0.054 & -0.3 & 15.872 \\
Maximum & 3.687 & 0.988 & 0.988 & 3.687 & 0.424 & 24.097 \\
\hline
\end{tabular}

\subsection{Multiple Regressions}

This study created a regression model in order to determine the impact of leverage, liquidity and cash flows from operations on company performance. The equation of the regression model used in this study is as follows:

$$
\text { Perfit }_{i t} \beta_{0}+\beta_{1} L E V_{i t}+\beta_{2} L I Q_{i t}+\beta_{3} C_{C F O}+\beta_{4} S_{\text {SIZ }} i t+\varepsilon_{i t}(1)
$$

The results from the regression model are presented in Table 3:

Table 3: Multiple Regression Results using ROA and ROE as Dependent Variable

\begin{tabular}{|c|c|c|c|c|}
\hline \multirow[b]{2}{*}{ Variables } & \multicolumn{2}{|c|}{ ROA } & \multicolumn{2}{|c|}{ ROE } \\
\hline & Coefficient & $\mathrm{t}$-value & Coefficient & $\mathrm{t}$-value \\
\hline Constant & -0.1236 & $-9.961^{* * *}$ & -0.1705 & $-6.777^{\star \star \star}$ \\
\hline LEV & -0.0001 & -0.035 & -0.0063 & -0.815 \\
\hline LIQ & 0.0067 & $5.916^{* * *}$ & 0.0077 & $3.360^{* * *}$ \\
\hline CFO & 0.1366 & $10.739^{\star * *}$ & 0.2131 & $8.266^{\star \star *}$ \\
\hline SIZE & 0.0054 & $8.724^{\star \star *}$ & 0.0077 & $6.046^{* \star *}$ \\
\hline Adjusted $R^{2}$ & 0.201 & & 0.114 & \\
\hline $\mathrm{F}$ value & $65.90^{\star \star *}$ & & $34.29^{* * *}$ & \\
\hline
\end{tabular}

Based on the results tabulated in Table 3, the adjusted $R^{2}$ of 0.201 describes that 20.10 per cent of financial performance represented by $R O A$ is affected by all variables tested in this study. Using ROE, the adjusted $\mathrm{R}^{2}$ is 0.114 or 11.4 per cent which is lower compared to ROA. The findings proved that other factors excluded in this study will have impact on company performance.

This study found that there is a significant positive impact of liquidity, cash flows from operations and company size on public listed companies' performance during the Covid-19 pandemic for both ROE and ROA being used as dependent variables, separately. Findings in Table 3 show that company leverage does not have any significant impact on company performance. It suggested that leverage does not affect performance on a short-term basis since this study used only the first two-quarters of financial data in 2020. This finding is consistent with lqbal and Usman (2018), who found that leverage has no significant impact on company performance represented by ROE.

This is probably due to many other factors that may impact the company performance during the Covid-19 pandemic outbreak in a bigger and significant way. However, leverage may have impact on company performance if longer periods were considered as samples. 
The liquidity ratio shows a positively significant relationship towards company performance, measured by ROA and ROE. This finding is aligned with the previous studies carried out by Apan and İslamoğlu, (2018) that found a positive relationship between liquidity and financial performance of the companies. As stated in the 2020 Report by Ernst and Young, due to the MCO imposed by the government, most of the companies have difficulties maintaining and managing their working capital (EY, 2020). Therefore, the result from this study is inconsistent with EY report and shows that the majority of the companies in this study are not yet affected by the Covid-19 pandemic and efficiently managing their assets in generating profit. It could be due to the fact that this study only used the first two quarters of financial data in the first-year pandemic hits Malaysia. Therefore, most of the public listed companies are still able to pay their short-term debts during this period.

Consistent with Frank \& James (2014), the result of this study suggests that cash flows from operation ratio have a positively significant relationship with both the company's performance, ROA, and ROE. This may be due to the cash flows from operations being the essential element in measuring a company's performance, whether they are successful in formulating positive cash flows from their business activities or not. On the other hand, it also shows how efficient the companies are in utilising their assets to collect cash from sales and customers. It is especially imperative to have positive cash flows from operations during the Covid-19 pandemic outbreak to fund a new product launch, a new marketing strategy, or paying off its debt. This study has proven that the cash flows from operations positively impacted company performance, ROA and ROE, narrowing down the literature gap as the previous study focused on a different aspect of the cash flows statement.

In this study, trade-off theory is deemed helpful in assisting company management in making proper business decisions predominantly during the Covid-19 pandemic outbreak. It is expected that companies must handle their liquidity to maintain and sustain their company's operations. The results in Tables 2 and 3 show that the companies' liquidity ratio is still high and more than 1 . It demonstrated that companies are able to manage and pay back their debts, particularly during the Covid-19 pandemic outbreak. In addition, cash flows from the operation of the companies also have a positive impact on company performance measured by ROA and ROE. This finding supports Orshi (2016) view that the company must balance in managing between the cost and benefits of liquidity and cash handling.

\subsection{Conclusion \& Recommendations}

This study examines the impact of company leverage, liquidity, and cash flows from operation ratio towards company performance measured by ROA and ROE for publicly listed companies on Bursa Malaysia during the Covid-19 pandemic outbreak. By using the first two-quarters of financial data in 2020, the findings of this study showed that the company liquidity and cash flows from operations significantly impact the companies' performance. However, the company performance is not affected by the company's leverage ratio. This study may contribute as additional literature to future studies. It may also provide insights to regulators on how companies cope with the economic slowdown due to the Covid-19 pandemic outbreak. The use of Python Pandas analysis may also contribute to the analysis method since there is still a shortage of Python Pandas studies in their data analysis method. Since machine learning has become a growing force and competitive in the business, its use may provide better results. Due to this study limited to the two-quarters of financial reports, the findings may not reflect the whole performance of the companies during the Covid-19 pandemic outbreak crisis. Thus, future research should consider extending the study period and other variables such as management efficiency and corporate governance components on companies' performance.

\section{Acknowledgements}

This work was financially supported by the Faculty of Accountancy, UiTM Puncak Alam, Selangor, Malaysia.

\section{Paper Contribution to Related Field of Study}

This study would contribute to statistical analysis in examining whether public listed companies in Malaysia are impacted positively or adversely by the Covid-19 pandemic outbreak for the professionals in the industry who act as practitioners. The importance to examine the public listed companies on the mainboard of Bursa Malaysia is to understand whether company leverage, liquidity and cash flows from operations do impose an impact towards company performance as the public listed companies are larger in size and are bound by the listing rules and regulations in order to stay listed. This study may also serve as additional information to the regulators on how public listed companies in Malaysia are coping with the Covid-19 pandemic outbreak and how to survive in the economic downturn, with the new normal and social distancing set by the government through the National Security Council and Ministry of Health.

\section{References}

Abdullah, H., \& Tursoy, T. (2021). Capital structure and firm performance: a panel causality test. MPRA Paper, 105871.

Alshammari, T. (2020). "Cash level and corporate performance: evidence from the Gulf Cooperation Council countries." Investment Management and Financial Innovations 17(4), 14-24. https://doi.org/10.21511/imfi.17(4).2020.02

Alslehat, M., \& Al-Nimer, M. (2017). Empirical study on the relationship between cashflow management and financial performance of Jordanian Insurance companies. International Business Management, 11(3), 776-782. https://doi.org/10.3923/ibm.2017.776.782

Apan, M., \& İslamoğlu, M. (2018). Determining the impact of financial characteristics on firm profitability: An empirical analysis on borsa Istanbul energy firms. WSEAS Transactions on Business and Economics, 15(May), 547-559. 
Chabachib, M., Setyaningrum, I., Hersugondo, H., Shaferi, I., \& Pamungkas, I. D. (2020). Does financial performance matter? Evidence on the impact of liquidity and firm size on stock return in Indonesia. International Journal of Financial Research, 11(4), 546-555. https://doi.org/10.5430/ijfr.v11n4p546

Che Omar, A. R., Ishak, S., \& Jusoh, M. A. (2020). The Impact Of Covid-19 Movement Control Order On SMEs' Businesses And Survival Strategies. Malaysian Journal of Society and Space, 16(2), 139-150. https://doi.org/10.17576/geo-2020-1602-11

EY. (2020). Covid-19: Business Impact Survey - Understanding the Now, Preparing for the Next and Beyond. Building A Better Working World, 8(7).

Foo, L. P., Chin, M. Y., Tan, K. L., \& Phuah, K. T. (2020). The impact of COVID-19 on tourism industry in Malaysia. Current Issues in Tourism, 1-5. https://doi.org/10.1080/13683500.2020.1777951

Frank, B. P., \& James, O. K. (2014). Performance : A Study of Selected Food and Beverages Companies in Nigeria. European Journal of Accounting Auditing and Finance Research, 2(7), 77-87.

Hasanat, M. W., Ashikul Hoque, F. A. S., Mashrekha Anwar, P., Dr., Hamid, A. B. A., \& Prof. Dr. Huam Hon Tat. (2020). The impact of coronavirus on business continuity planning. Asian Journal of Multidisciplinary Studies, 3(1), 85-90. https://searchdisasterrecovery.techtarget.com/The-impact-of-coronavirus-on-business-continuityplanning?track=NL-1822\&ad=932824\&src=932824\&asrc=EM_NLN_124631071\&utm_medium=EM\&utm_source=NLN\&utm_campaign=20200310_Is your business continuity plan

Hassan, L., \& Samour, S. (2015). Capital Structure and Firm Performance: Did the Financial Crisis Matter? -A cross-industry study [Uppsala University]. http://www.divaportal.org/smash/get/diva2:944378/FULLTEXT01.pdf

Hedija, V., \& Němec, D. (2021). Gender diversity in leadership and firm performance: Evidence from the czech republic. Journal of Business Economics and Management, 22(1), 156-180. https://doi.org/10.3846/jbem.2020.13680

International Monetary Fund. (2020). Debt Management Responses to the Pandemic, IMF COVID-19 Special Series. Mcmdm, 1-13.

Iqbal, U., \& Usman, M. (2018). Impact of Financial Leverage on Firm Performance. SEISENSE Journal of Management, 1(2), 70-78. https://doi.org/10.33215/sjom.v1i2.13

Lee, K. D. (2014). Python Programming Fundamentals. In Springer: Vol. second edi. https://doi.org/10.5860/choice.48-5136

Li, K., Musah, M., Kong, Y., Adjei Mensah, I., Antwi, S. K., Bawuah, J., Donkor, M., Coffie, C. P. K., \& Andrew Osei, A. (2020). Liquidity and Firms' Financial Performance Nexus: Panel Evidence From Non-Financial Firms Listed on the Ghana Stock Exchange. SAGE Open, 10(3), 1-20. https://doi.org/10.1177/2158244020950363

Liang, D., Tsai, C. F., Lu, H. Y. (Richard), \& Chang, L. S. (2020). Combining corporate governance indicators with stacking ensembles for financial distress prediction. Journal of Business Research, 120(July), 137-146. https://doi.org/10.1016/j.jbusres.2020.07.052

Majumdar, S. K. (1997). The impact of size and age on firm-level performance: Some evidence from India. Review of Industrial Organization, 12(2), 231-241. https://doi.org/10.1023/A:1007766324749

Orshi, T. S. (2016). Impact of liquidity management on the financial performance of listed food and beverages companies in Nigeria (Issue January) [NIGERIAN DEFENCE ACADEMY, KADUNA]. https://doi.org/10.13140/RG.2.2.27672.80644

Purwanto, A., Fahlevi, M., Zuniawan, A., Kusuma, R. D. P., Supriatna, H., \& Maryani, E. (2020). the Covid-19 Pandemic Impact on Industries Performance: an Explorative Study of Indonesian. Journal of Critical Reviews, 7(15), 1965-1972.

Rajamoorthy, Y. (2020). Impact of Corona Virus Outbreak on Malaysian Trade. SSRN Electronic Journal, January, 1-7. https://doi.org/10.2139/ssrn.3571386

Shafi, M., Liu, J., \& Ren, W. (2020). Impact of COVID-19 pandemic on micro, small, and medium-sized Enterprises operating in Pakistan. Research in Globalization, 2(100018), 2-14. https://doi.org/10.1016/j.resglo.2020.100018

Shen, H., Fu, M., Pan, H., Yu, Z., \& Chen, Y. (2020a). The Impact of the COVID-19 Pandemic on Firm Performance. Emerging Markets Finance and Trade, 56(10), 22132230. https://doi.org/10.1080/1540496X.2020.1785863

Shen, H., Fu, M., Pan, H., Yu, Z., \& Chen, Y. (2020b). The Impact of the COVID-19 Pandemic on Firm Performance. Emerging Markets Finance and Trade, 56(10), 22132230. https://doi.org/10.1080/1540496X.2020.1785863

Tahir, M. S., Alifiah, M. N., Arshad, M. U., \& Saleem, F. (2016). Financial theories with a focus on corporate cash holding behavior: A comprehensive review. International Journal of Economics and Financial Issues, 6(3), 215-219.

Tang, K. H. D. (2020). Movement control as an effective measure against Covid-19 spread in Malaysia: an overview. Journal of Public Health: From Theory to Practice, 1720. https://doi.org/10.1007/s10389-020-01316-w

Wijewardana, \& Munasinghe. (2018). Cash Flows and Firm Performance: Some Evidence from the Sri Lankan Firms Cash Flow. SSRN Electronic Journal, 2(1), 41-48. https://doi.org/10.2139/ssrn.2795323

Zhang, W., von Eije, H., \& Westerman, W. (2015). Does Cash Contribute to Value? A Comparison of Constrained and Unconstrained Firms in China and Germany. Eurasian Journal of Economics and Finance, 3(4), 22-38. https://doi.org/10.15604/ejef.2015.03.04.003

Zimon, G., \& Dankiewicz, R. (2020). Trade credit management strategies in SMEs and the COVID-19 pandemic-a case of Poland. Sustainability, 12(6114), 1-16. https://doi.org/10.3390/su12156114 